\title{
INHIBITORY EFFECTS OF CLONIDINE ON SEROTONERGIC NEURONAL ACTIVITY AS MEASURED BY CEREBROSPINAL FLUID SEROTONIN AND ITS METABOLITE IN ANESTHETIZED RATS
}

\author{
Machiko Matsumoto, Hiroko Togashi, Mitsuhiro Yoshioka, Mitsugu Hirokami, Masahiro Tochihara, \\ Toshiya Ikeda, *Charles B. Smith and Hideya Saito.
}

First Department of Pharmacology, Hokkaido University School of Medicine, Sapporo 060, Japan, *Department of Pharmacology, University of Michigan Medical School, Ann Arbor, MI 48109-0626, U.S.A.

\author{
(Received in final form June 3, 1993)
}

\begin{abstract}
Summary
Clonidine-induced changes in the serotonergic neuronal activity of the central nervous system were estimated by measuring the concentrations of scrotonin $(5-\mathrm{HT})$ and its major metabolite, 5-hydroxyindole-3-acetic acid (5-HIAA), in the cerebrospinal fluid (CSF) of anesthetized rats. Clonidine ( 30 and $300 \mu \mathrm{g} / \mathrm{kg}$, i.v.) led to $74 \%$ and $60 \%$ reductions in the concentration of $5-\mathrm{HT}$ in the CSF $60 \mathrm{~min}$ after administration. CSF 5-HIAA concentrations were also decreased to $77 \%$ and $66 \%$, respectively. Clonidine-induced ( $30 \mu \mathrm{g} / \mathrm{kg}$, i.v.) decreases in CSF 5-HT and 5HIAA concentrations were attenuated by pretreatment with idazoxan $(5 \mathrm{mg} / \mathrm{kg}$, i.p.). Idazoxan by itself did not alter the CSF 5-HT and 5-HIAA concentrations. Decreased CSF 5-HT and 5HIAA concentrations after i.v. administration of clonidine $(30 \mu \mathrm{g} / \mathrm{kg})$ werc abolished by noradrenergic denervation after pretreatment with 6 -hydroxydopamine $(200 \mu \mathrm{g} / \mathrm{rat}$, i.c.v.). These results suggest the possibility that clonidine acts to inhibit the serotonergic neuronal activity, which is mediated via the $\alpha_{2}$-adrenoceptors. It indicates, moreover, that noradrenergic nervous systems are involved in the clonidine-induced inhibition of serotonergic neuronal activity. Therefore, noradrenergic neurons play a significant role in mediating the actions of clonidine on serotonergic neuronal activity in the rat brain.
\end{abstract}

Anatomical studies indicate that numerous brain regions receive both serotonergic and noradrenergic projections mainly from the raphe nucleus (1) and the locus coeruleus (2), respectively. The presence of both serotonergic and noradrenergic neurons in the same brain area suggests that a functional interaction exists between the two neuronal systems. Thus, the activity of serotonergic neurons, as reflected by serotonin (5-HT) turnover, might be modulated by noradrenergic nervous systems or, conversely, the activity of noradrenergic neurons might be regulated by serotonergic nervous systems. It is well known that clonidine, an $\alpha 2$-adrenoceptor agonist, acts either directly at noradrenergic neuronal cell bodies to inhibit neuronal activity in areas of the brain such as the locus coeruleus $(3,4)$ or at presynaptic autorcgulatory receptors to inhibit neurotransmitter release (5-7). Biochemical studies have provided evidence that clonidine also affects serotonergic neuronal function. Reinhard and Robert (8) reported that clonidine decreased the accumulation of 5-hydroxytryptophan (5-HTP), the serotonin (5-HT) precursor, and reduced the content of 5-hydroxyindole-3-acetic acid (5-HIAA), the major metabolite of 5HT, in the rat cerebral cortex. Geyer and Lee $(9)$ found that clonidine inhibited 5-HT turnover in the rat dorsal raphe nuclus and striatum. In contrast, Maj et al. (10) reported that clonidine increased the 5-HT content of the rat whole brain. Clement et al. (11) showed that high dose of clonidine increased extraneuronal 5-HIAA levels in the rat nucleus raphe dorsalis, whereas low dose of clonidine decreased them. Thus, whether clonidine modulates the serotonergic nervous system remains to be ascertained.

In an attempt to estimate serotonergic or noradrenergic neuronal activity, mordern neurochemical methods such as in vivo microdialysis, in vivo voltammetry, push-pull cannulation and sampling of cerebrospinal fluid (CSF) have been applied to measure extracellular levels of 5-HT or noradrenaline (NA) in various brain regions. Among these approaches, CSF determination of 5-HT (or NA) concentrations is advantageous for assessment of the global neuronal activity in the central nervous systems. Since this method enables repeated sampling without tissue destruction, it would be a useful methods, were if available clinically, for the assessment of central serotonergic or noradrenergic neuronal activity. Some investigators have measured CSF NA concentrations to evaluate pharmacologically noradrenergic neuronal activity. For instance, CSF NA concentrations in humans (12) and animals (13) decreased following administration of an $\alpha 2$-adrenoceptor agonist, e.g., clonidine and xylazine, respectively. Few reports are available, however, on the measurement of CSF 5-HT concentrations following drug 
administration due to the difficulty of analytical techniques. Moreover, Anderson et al. (14) have recently pointed out that the clinical utility of human CSF 5-HT determination is in question because of its extremely low levels. Therfore, the pharmacological significance of CSF 5-HT concentrations has not been established.

Recently, we have developed a technique of combinig high-performance liquid chromatography (HPLC) with electrochemical detection (ECD) that enables the simultaneous measurement of 5-HT and 5-HIAA concentrations in small amounts of rat CSF (15). With this method, we have demonstrated that CSF 5-HT levels provide a direct indication of central serotonergic neuronal activity (16). The present study was undertaken to evaluate the pharmacological significance of CSF 5-HT concentrations. For this purpose, the modulation of serotonergic neuronal activity by clonidine was investigated through the determination of CSF 5-HT and 5-HIAA concentrations using HPLC-ECD. Focus was placed on the following points : 1) the effect of intravenous administration of clonidine on CSF 5-HT and 5-HIAA concentrations in anesthetized rats; and 2) the effect of selective $\alpha_{2}$-adrenoceptor antagonist, idazoxan, on clonidine-induced changes in CSF 5-HT and 5-HIAA concentrations. Furthermore, in order to investigate whether the pharmacological effects of clonidine on serotonergic neurons involve noradrenergic mechanisms, experiments were performed on rats that were chemically denervated by pretreatement with catecholamine neurotoxin, 6-hydroxydopamine (6-OHDA).

\section{Methods}

Generals: Male Wistar rats from 15 to 20 weeks of age weighing 250 to $350 \mathrm{~g}$ were anesthetized by the intraperitoneally (i.p.) injection of $\alpha$-chloralose, $50 \mathrm{mg} / \mathrm{kg}$, and urethane, $500 \mathrm{mg} / \mathrm{kg}$. A polyethylene cannula $(2.5 \mathrm{~cm} \times 0.6 \mathrm{~mm}$, I.D.) was inserted into the cisterna magna via the atlanto-occipital membrane under a Wild M650 stereoscopic dissecting microscope. Thirty minutes after cannulation, CSF was allowed to flow by gravity from the cisterna magna via a microhematocrit tube $(7.5 \mathrm{~cm} \times 1.5 \mathrm{~mm}$, I.D.) into iced vials. The CSF sampling flow rate was approximately $20 \mu \mathrm{l} / \mathrm{min}$. Although a sampling volume of $5 \mu \mathrm{l}$ was sufficient to determine CSF 5 HIAA concentrations, a volume of 40-50 $\mu \mathrm{l}$ was nessasary for simultaneous determination of both 5-HIAA and 5HT from the same sample because of the extremely low concentration of 5-HT in the CSF. The total CSF sampling volume never exceeded $150 \mu \mathrm{l}$ for any rat. Each fraction was examined cytologically for contamination with blood. Intravenous administration (i.v.) of clonidine $(3,30$ and $300 \mu \mathrm{g} / \mathrm{kg}$ ) or saline $(0.5 \mathrm{ml} / \mathrm{kg})$ was performed via a cannula inserted into the femoral vein. Idazoxan $(5 \mathrm{mg} / \mathrm{kg}$, i.p.) was injected $10 \mathrm{~min}$ before i.v. administration of clonidine $(30 \mu \mathrm{g} / \mathrm{kg})$. Blood pressure and heart rate were monitored continuously via the femoral artery with a pressure transducer (Nihon Kohden, Tokyo, Japan). Rectal temperature was maintained between 37 and $38^{\circ} \mathrm{C}$ with a heating pad. In order to chemically denervate the noradrenergic neurons, rats were anesthetized with ketamine (100 mg/kg, i.p), and 6-OHDA (200 $\mu \mathrm{g} / \mathrm{rat})$ was injected intracerebroventricularly (i.c.v.) using a stereotaxic apparatus. The rats in these experiments were injected with pargyline $(25 \mathrm{mg} / \mathrm{kg}$, i.p $) 10$ min before the administration of 6-OHDA. Effccts of clonidine upon CSF 5-HT and 5-HIAA concentrations were determined 14 days after the i.c.v. injection of neurotoxin.

Analysis: Fourty - $50 \mu 1$ of unprocessed CSF was injected directly into the HPLC within a few minutes following the sampling. 5-HT and 5-HIAA were measured by ECD as described previously (16). As an index of noradrenergic neuronal activity (17), the CSF concentration of 3,4-dihydroxypehynlacetic acid (DOPAC) was determined simultaneously with 5-HT and 5-HIAA. The HPLC-ECD system consisted of a pump (EP-10) coupled to a reversed phase column (MA-5ODS, ODS, $5 \mu \mathrm{m}$ particle sizc) and an electrochemical detector (ECD100). All equipment was purchased from Eicom, Co., Ltd (Kyoto, Japan). The mobile phase consisted of citric acid-sodium acetate buffer (pH 3.5), $10 \mu \mathrm{M}$ EDTA-2Na and $230 \mathrm{mg} / 1$ 1-octancsulfonate. 15-18\% (V/V) methanol was added to this solution depending on the column conditions.

Drugs: Clonidine hydrochloride (Sigma Chemical Co., St.Louis, MO. USA), idazoxan hydrochloride (Reckitt and Colman, Jull, UK), 6-OHDA hydrochloride (Sigma) and pargyline hydrochloride (Sigma) were used.

Statistics: Statistical comparisons were carried out using analysis of variance followed by Student's t-test. Values of $p$ less than $5 \%$ were considered significant. All results were expressed as mean \pm SEM.

\section{Results}

CSF 5-HT concentrations: Basal levels of CSF 5-HT, measured $30 \mathrm{~min}$ after cannulation and immediately before administration of clonidine $(3,30$ or $300 \mu \mathrm{g} / \mathrm{kg}, \mathrm{i} . \mathrm{v})$, did not differ significantly from the levels of saline-treated control rats. The CSF 5-HT concentrations were increased $60 \mathrm{~min}$ after treatment of rats with saline $(15.8 \pm 9.5 \%$ increase, n.s.). There was no further change in the CSF 5-HT concentrations $120 \mathrm{~min}$ after saline administration. In contrast, clonidine decreased the CSF 5-HT concentrations dose-dependently. Sixty minutes after administration, clonidine $(30 \mu \mathrm{g} / \mathrm{kg}$, i.v) caused a significant $26.2 \pm 13.0 \%$ decrease in CSF 5 -HT from basal levels and a significant $42.0 \%$ decrease in CSF 5-HT from levels measured in saline-treated animals at the same point in time. There was no further change in the CSF 5-HT concentrations $120 \mathrm{~min}$ after administration of 
clonidine. Clonidine $(300 \mu \mathrm{g} / \mathrm{kg}$, i.v.) significantly caused a decrease in CSF 5-HT concentrations from either basal levels or those measured in saline-treated animals at the same point in time (Table I).

\section{TABLE I}

Effects of Clonidine on Cerebrospinal Fluid (CSF) 5-HT Concentrations (pg/ml).

\begin{tabular}{|c|c|c|c|c|c|c|}
\hline Groups & (n) & $0 \mathrm{~min}$ & $60 \mathrm{~min}$ & $\%$ Change & $120 \mathrm{~min}$ & \% Change \\
\hline Control & (6) & $\begin{array}{l}384.98 \\
\pm 82.01\end{array}$ & $\begin{array}{l}450.02 \\
\pm 113.35\end{array}$ & $\begin{array}{l}15.83 \\
\pm 9.50\end{array}$ & $\begin{array}{l}447.91 \\
\pm 102.35\end{array}$ & $\begin{array}{l}15.99 \\
\pm 8.89\end{array}$ \\
\hline $\begin{array}{l}\text { Clonidine } \\
(3 \mu \mathrm{g} / \mathrm{kg}, \mathrm{i}, \mathrm{v} .)\end{array}$ & (4) & $\begin{array}{l}306.42 \\
\pm 60.43\end{array}$ & $\begin{array}{l}228.57 \\
\pm 61.49\end{array}$ & $\begin{array}{l}-17.82 \\
+21.94\end{array}$ & $\begin{array}{l}211.52 \\
\pm 36.31\end{array}$ & $\begin{array}{l}-15.88 \\
+35.85\end{array}$ \\
\hline $\begin{array}{l}\text { Clonidine } \\
(30 \mu \mathrm{g} / \mathrm{kg}, \mathrm{i} . \mathrm{v} .)\end{array}$ & (5) & $\begin{array}{l}466.92 \\
\pm 120.12\end{array}$ & $\begin{array}{l}326.10 \\
\pm 80.35\end{array}$ & $\begin{array}{l}-26.15^{*} \\
\pm 12.96\end{array}$ & $\begin{array}{l}341.55 \\
\pm 108.43\end{array}$ & $\begin{array}{l}-25.52^{*} \\
\pm 14.43\end{array}$ \\
\hline $\begin{array}{l}\text { Clonidine } \\
(300 \mu \mathrm{g} / \mathrm{kg} \text {, i.v. })\end{array}$ & (6) & $\begin{array}{l}344.98 \\
\pm 137.63\end{array}$ & $\begin{array}{l}192.58 \\
\pm 74.73\end{array}$ & $\begin{array}{l}-39.89 * * \\
\pm 12.76\end{array}$ & $\begin{array}{r}191.09 \\
\pm 72.89\end{array}$ & $\begin{array}{l}-51.19^{* *} \\
\pm 14.68\end{array}$ \\
\hline $\begin{array}{l}\text { I d azo o a n } \\
(5 \mathrm{mg} / \mathrm{kg}, \text { i.p. })\end{array}$ & (5) & $\begin{array}{l}319.53 \\
\pm 107.08\end{array}$ & $\begin{array}{l}277.25 \\
\pm 35.54\end{array}$ & $\begin{array}{l}9.44 \\
\pm 22.30\end{array}$ & $\begin{array}{l}307.77 \\
\pm 113.45\end{array}$ & $\begin{array}{l}-8.76 \\
\pm 9.63\end{array}$ \\
\hline $\begin{array}{l}\text { Idazoxan(5 mg/kg,i.p.) } \\
\text { +Clonidine } \\
\text { (30 } \mathrm{gg} / \mathrm{kg} \text { i.v. }\end{array}$ & (5) & $\begin{array}{l}307.93 \\
80.13\end{array}$ & $\begin{array}{l}258.90 \\
\pm 49.05\end{array}$ & $\begin{array}{l}-5.22 \\
\pm 17.53\end{array}$ & $\begin{array}{l}234.81 \\
\pm 45.72\end{array}$ & $\begin{array}{l}-16.54 \\
\pm 12.26\end{array}$ \\
\hline $\begin{array}{l}\text { 6.OHDA }(200 \mu \mathrm{g}, \text { i.c.v. }) \\
\text { + Clonidine } \\
(30 \mu \mathrm{g} / \mathrm{kg}, \mathrm{i.v.})\end{array}$ & (5) & $\begin{array}{l}342.88 \\
\pm 50.88\end{array}$ & $\begin{array}{l}423.69 \\
\pm 90.59\end{array}$ & $\begin{array}{l}54.35 \\
\pm 78.06\end{array}$ & $\begin{array}{l}350.46 \\
\pm 12.47\end{array}$ & $\begin{array}{l}22.97 \\
\pm 27.33\end{array}$ \\
\hline
\end{tabular}

Data presented are mean \pm SEM. ${ }^{*} \mathrm{p}<0.05$ and ${ }^{* *} \mathrm{p}<0.01$ compared 6 controls.

CSF 5-HIAA concentrations: Basal levels of CSF 5-HIAA measured before administration of either saline or clonidine $(3,30$ or $300 \mu \mathrm{g} / \mathrm{kg}, \mathrm{i} . \mathrm{v})$ did not differ significantly from the levels of normal rats. The CSF 5-HIAA concentrations were not significantly changed $60 \mathrm{~min}$ and $120 \mathrm{~min}$ after treatment with saline. Clonidine, 3 $\mu \mathrm{g} / \mathrm{kg}$, i.v., did not affect the CSF 5-HIAA concentrations, while 30 and $300 \mu \mathrm{g} / \mathrm{kg}$, i.v. decreased significantly the CSF 5-HIAA concentrations. Sixty minutes after administration, clonidine, $30 \mu \mathrm{g} / \mathrm{kg}$, i.v., caused a $23.1 \pm$ 4.3\% decrease in CSF 5-HIAA from basal levels and a 31.0\% decrease in CSF 5-HIAA concentration from levels measured in saline-treated animals at the same point in time. There was no further change in the CSF 5-HIAA concentrations $120 \mathrm{~min}$ after administration. Clonidine, $300 \mu \mathrm{g} / \mathrm{kg}$, i.v., caused a significant and dose-dependent decrease in CSF 5-HIAA from either basal levels or those measured in saline-treated animals at the same point in time (Table II).

CSF DOPAC concentrations: Basal levels of CSF DOPAC in clonidine-administered groups did not significantly differ from those of saline treated control rats. The CSF DOPAC concentrations were not significantly changed 60 $\mathrm{min}$ and $120 \mathrm{~min}$ after saline administration. Clonidine $(3,30$ and $300 \mu \mathrm{g} / \mathrm{kg}, \mathrm{i} . \mathrm{v}$.) decreased the CSF DOPAC concentrations in a dose-dependent manner (Table III).

Idazoxan pretreatment: In order to confirm the involvement of $\alpha_{2}$-adrenoceptors in the clonidine-induced decreases of CSF 5-HT and 5-HIAA concentrations, a specific $\alpha 2$-adrenoceptor antagonist, idazoxan, was used. Basal levels of CSF 5-HT and 5-HIAA in idazoxan treated rats did not differ from those of either saline- or clonidineadministered rats. Idazoxan $(5 \mathrm{mg} / \mathrm{kg}$, i.p) by itself did not significantly alter CSF 5 -HT and 5-HIAA concentrations. Pretreatment with idazoxan $(5 \mathrm{mg} / \mathrm{kg}$, i.p.) attenuated the decreased CSF 5-HT and 5-HIAA concentrations $60 \mathrm{~min}$ and $120 \mathrm{~min}$ after $\mathrm{i} . \mathrm{v}$. administration of clonidine $(30 \mu \mathrm{g} / \mathrm{kg})$ (Table I and II). Clonidine (30 $\mu \mathrm{g} / \mathrm{kg}$, i.v.)-induced decreases in CSF DOPAC concentrations were also abolished significantly by pretreatment with idazoxan (Table III).

6-OHDA pretreatment: In rats pretreated with 6-OHDA, basal levels of both CSF 5-HT and 5-HIAA did not significantly differ from those of non-lesioned normal rats. CSF DOPAC concentrations in 6-OHDA pretreated rats were $5.30 \pm 1.02 \mathrm{ng} / \mathrm{ml}$, which represented a significant $70 \%$ reduction compared with the levels in nonlesioned rats $(<0.001)$. In $6-O H D A$ pretreated rats, clonidine $(30 \mu \mathrm{g} / \mathrm{kg}, \mathrm{i} . \mathrm{v})$ failed to decrease CSF 5 -HT concentrations $60 \mathrm{~min}$ and $120 \mathrm{~min}$ after administration (Table I). Clonidine-induced decreases in CSF 5-HIAA levels were also significantly inhibited by 6-OHDA pretreatment (Table II). 
TABLE II

Effects of Clonidine on Cerebrospinal Fluid (CSF) 5-HIAA Concentrations ( $\mathrm{ng} / \mathrm{ml}$ ).

\begin{tabular}{|c|c|c|c|c|c|c|}
\hline Groups & (n) & $0 \mathrm{~min}$ & $60 \mathrm{~min}$ & $\%$ Change & $120 \mathrm{~min}$ & $\%$ Change \\
\hline Control & (7) & $\begin{array}{l}199.89 \\
\pm 19.14\end{array}$ & $\begin{array}{l}216.67 \\
\pm 26.72\end{array}$ & $\begin{array}{l}7.92 \\
\pm 9.37\end{array}$ & $\begin{array}{l}196.94 \\
\pm 21.82\end{array}$ & $\begin{array}{l}-1.16 \\
\pm 6.27\end{array}$ \\
\hline $\begin{array}{l}\text { Clon id ine } \\
(3 \mu \mathrm{g} / \mathrm{kg}, \text { i.v. })\end{array}$ & (4) & $\begin{array}{l}177.88 \\
\pm 20.74\end{array}$ & $\begin{array}{l}157.91 \\
\pm 22.43\end{array}$ & $\begin{array}{l}-3.47 \\
\pm 1.96\end{array}$ & $\begin{array}{r}190.44 \\
\pm 36.64\end{array}$ & $\begin{array}{l}4.25 \\
\pm 8.53\end{array}$ \\
\hline $\begin{array}{l}\text { Clonidine } \\
(30 \mu g / k g, i . v .)\end{array}$ & (5) & $\begin{array}{l}175.63 \\
\pm 21.15\end{array}$ & $\begin{array}{l}134.19 \\
\pm 16.19\end{array}$ & $\begin{array}{l}-23.12^{*} \\
\pm 4.31\end{array}$ & $\begin{array}{l}129.91 \\
\pm 14.43\end{array}$ & $\begin{array}{l}-24.82 * * \\
\pm 5.79\end{array}$ \\
\hline $\begin{array}{l}\text { Clon id ine } \\
(300 \mu \mathrm{g} / \mathrm{kg}, \text { i.v. })\end{array}$ & (6) & $\begin{array}{l}183.97 \\
\pm 12.15\end{array}$ & $\begin{array}{l}121.19 \\
\pm 17.20\end{array}$ & $\begin{array}{l}-34.08 * * \\
\pm 8.32\end{array}$ & $\begin{array}{l}109.30 \\
\pm 23.44\end{array}$ & $\begin{array}{l}-40.42 * * \\
\pm 9.25\end{array}$ \\
\hline $\begin{array}{l}\text { I d a zo } x \text { a n } \\
(5 \mathrm{mg} / \mathrm{kg}, \text { i.p. })\end{array}$ & (5) & $\begin{array}{l}170.02 \\
\pm 21.13\end{array}$ & $\begin{array}{l}181.67 \\
\pm 18.77\end{array}$ & $\begin{array}{l}10.12 \\
\pm 10.47\end{array}$ & $\begin{array}{l}177.20 \\
\pm 20.92\end{array}$ & $\begin{array}{l}7.20 \\
\pm 10.48\end{array}$ \\
\hline $\begin{array}{l}\text { Idazoxan(5 mg/kg,i.p.) } \\
+ \text { Clonidine } \\
(30 \mu \mathrm{g} / \mathrm{kg}, \text { i.v. })\end{array}$ & (5) & $\begin{array}{l}147.26 \\
\pm 17.92\end{array}$ & $\begin{array}{l}163.37 \\
\pm 19.52\end{array}$ & $\begin{array}{l}12.38 \# \# \\
\pm 8.12\end{array}$ & $\begin{array}{l}166.26 \\
\pm 16.81\end{array}$ & $\begin{array}{l}16.32 \# \# \\
\pm 10.76\end{array}$ \\
\hline 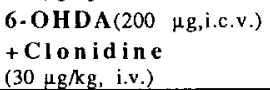 & (5) & $\begin{array}{l}143.83 \\
\pm 14.62\end{array}$ & $\begin{array}{l}140.15 \\
\pm 13.85\end{array}$ & $\begin{array}{l}-1.33 \# \\
\pm 7.12\end{array}$ & $\begin{array}{l}111.00 \\
\pm 10.22\end{array}$ & $\begin{array}{l}-22.21 \\
\pm 11.01\end{array}$ \\
\hline
\end{tabular}

Data presented are mean \pm SEM. ${ }^{*} \mathrm{p}<0.05$ and ${ }^{* *} \mathrm{p}<0.01$ compared to controls.

\# $\mathrm{p}<0.05$ and \#\# $\mathrm{p}<0.01$ compared to clonidine $(30 \mu \mathrm{g} / \mathrm{kg}$, i.v.) treated rats.

TABLE III

Effects of Clonidine on Cerebrospinal Fluid (CSF) DOPAC Concentrations ( $\mathrm{ng} / \mathrm{ml}$ ).

\begin{tabular}{|c|c|c|c|c|c|c|}
\hline Groups & (n) & $0 \mathrm{~min}$ & $60 \mathrm{~min}$ & \%Change & $120 \mathrm{~min}$ & \% Change \\
\hline Control & (6) & $\begin{array}{l}17.88 \\
\pm 2.54\end{array}$ & $\begin{array}{l}19.29 \\
\pm 2.88\end{array}$ & $\begin{array}{l}14.93 \\
\pm 18.44\end{array}$ & $\begin{array}{l}17.54 \\
\pm 2.30\end{array}$ & $\begin{array}{l}5.92 \\
\pm 9.93\end{array}$ \\
\hline $\begin{array}{l}\text { Clonidine } \\
(3 \mu \mathrm{g} / \mathrm{kg}, \mathrm{i} . \mathrm{v} .)\end{array}$ & (4) & $\begin{array}{l}15.01 \\
\pm 2.45\end{array}$ & $\begin{array}{l}14.17 \\
\pm 2.82\end{array}$ & $\begin{array}{l}-8.13 \\
\pm 4.06\end{array}$ & $\begin{array}{l}12.61 \\
\pm 1.71\end{array}$ & $\begin{array}{l}-14.17 \\
\pm 4.88\end{array}$ \\
\hline $\begin{array}{l}\text { Clonidine } \\
(30 \mu g / k g, \text { i.v. })\end{array}$ & (5) & $\begin{array}{l}18.83 \\
\pm 3.77\end{array}$ & $\begin{array}{l}10.63 \\
\pm 1.37\end{array}$ & $\begin{array}{l}-38.39^{*} \\
\pm 9.28\end{array}$ & $\begin{array}{l}9.52 \\
\pm 0.96\end{array}$ & $\begin{array}{l}-43.16^{* *} \\
\pm 9.57\end{array}$ \\
\hline $\begin{array}{l}\text { CIon id i ne } \\
(300 \mu g / k g \text {, i.v. })\end{array}$ & (6) & $\begin{array}{l}23.41 \\
\pm 3.79\end{array}$ & $\begin{array}{l}11.29 \\
\pm 1.64\end{array}$ & $\begin{array}{l}-46.09^{* *} \\
\pm 10.17\end{array}$ & $\begin{array}{l}11.41 \\
\pm 3.00\end{array}$ & $\begin{array}{l}-48.60^{* *} \\
\pm 8.32\end{array}$ \\
\hline $\begin{array}{l}\text { I d a zo x a n } \\
(5 \mathrm{mg} / \mathrm{kg}, \text { i.p. })\end{array}$ & (4) & $\begin{array}{l}18.47 \\
\pm 1.96\end{array}$ & $\begin{array}{l}18.90 \\
\pm 3.54\end{array}$ & $\begin{array}{l}0.43 \\
\pm 12.17\end{array}$ & $\begin{array}{l}17.12 \\
\pm 2.60\end{array}$ & $\begin{array}{l}-1.35 \\
\pm 12.08\end{array}$ \\
\hline $\begin{array}{l}\text { Idazoxan }(5 \mathrm{mg} / \mathrm{kg}, \mathrm{i} . \mathrm{p} .) \\
+ \text { Clon idine } \\
(30 \mu g / \mathrm{kg}, \text { i.v. })\end{array}$ & (5) & $\begin{array}{l}16.34 \\
\pm 1.43\end{array}$ & $\begin{array}{l}17.12 \\
\pm 0.68\end{array}$ & $\begin{array}{l}7.50 \# \# \\
\pm 8.72\end{array}$ & $\begin{array}{l}17.65 \\
\pm 1.68\end{array}$ & $\begin{array}{l}11.67 \# \\
\pm 14.00\end{array}$ \\
\hline
\end{tabular}

Data presented are mean \pm SEM. ${ }^{*} p<0.05$ and ${ }^{* *} p<0.01$ compared to controls.

$\# \mathrm{p}<0.05$ and \#\# $\mathrm{p}<0.01$ compared to clonidine $(30 \mu \mathrm{g} / \mathrm{kg}$, i.v.) treated rats.

\section{Discussion}

The present study revealed that clonidine produced dose-dependent decreases in CSF 5-HT concentrations in anesthetized rats. CSF 5-HIAA concentrations also decreased after clonidine administration. Clonidine-induced 
decreases in CSF 5-HT and 5-HIAA concentrations were attenuated by pretreatment with idazoxan. Idazoxan by itself did not alter either CSF 5-HT or 5-HIAA levels. These results suggest the possibility that clonidine acts to inhibit the central serotonergic neuronal activity via the $\alpha 2$-adrenoceptors. Furthermore, it indicates that the serotonergic neuronal activity is not tonically influenced by $\alpha_{2}$-adrenoceptors. The clonidine-induced decreases in both CSF 5-HT and 5-HIAA concentrations were abolished by noradrenergic denervation caused by pretreatment of 6-OHDA. Thus, the noradrenergic nervous system might be involved in the inhibitory effect of clonidine on serotonergic neuronal activity. In this experiment, clonidne decreased CSF DOPAC concentrations dosedependently and these effects were significantly abolished by the pretreatment with idazoxan. Our findings were in agreement with reports by Tibirica et al. (18) who showed, using in vivo voltammetry, that the DOPAC oxidation peak in both locus coeruleus and nucleus reticularis lateralis was decreased by clonidine. Their electrophysiological studies have shown that a correlation between the amplitude of the DOPAC peak and the firing rate of the noradrenergic neurons, i.e., the DOPAC peak can be used as an index of the functional activity of noradrenergic neurons. Our previous data also indicated that CSF DOPAC concentrations reflect the central noradrenergic neuronal activity, since CSF DOPAC concentrations correlated positively with brain NA contents in rats (unpublished data). The present fact that clonidine-induced decreases in CSF DOPAC concentrations were inhibited by pretreatment with idazoxan confirmed, therefore, that clonidine acts to inhibit noradrenergic neurons via the $\alpha_{2-}$ adrenoceptors. Taken together, they support the possibility that noradrenergic nervous systems may be involved in the inhibitory effects of clonidine on serotonergic neuronal activity.

There are many speculations about the mechanism of the inhibitory effects of clonidine on serotonergic neuronal activity, i.e., clonidine produced decreases in both 5-HT and 5-HIAA concentrations in the CSF. One possibility is that clonidine modulates the biosynthesis, not the metabolism, of 5-HT neurons. This hypothesis is supported by the report that systemic administration of clonidine decreased 5-HTP accumulation in the rat cerebral cortex (8). We have also observed that 5-HTP accumulation in the rat dorsal raphe nucleus and hippocampus were decreased by clonidine (19). Another possibility is that clonidine suppresses the 5-HT release from the nerve terminals. Some in vitro studies have demonstrated the presence of $\alpha_{2}$-adrenoceptors on serotonergic nerve terminals in the rat brain $(20,21)$. Recently we have showed that the physiological modulation of clonidine on 5 HT release via the $\alpha_{2}$-adrenoceptors, which are located on the scrotonergic nerve terminals, exists in the rat hippocampus (22). Although more detailed studies are needed with regard to these mechanisms, the CSF 5-HT and 5 -HIAA concentrations certainly could reflect the global neuronal activity including biosynthesis and/or release of 5-HT.

The source of CSF 5-HT has been unclear. Anatomical and histochemical evidence have revealed the distribution of serotonergic neurons : the choroid plexus, the major site of CSF production, which is innervated by serotonergic and noradrenergic nerves (23). The brainstem, including the raphe nucleus which contains the highest density of 5-HT cell bodies, is adjacent to the third ventricle. The dorsal raphe nucleus receives direct projections of noradrenergic nerve terminals from the locus coeruleus (1). Furthermore, the ventromedial raphe magnus contains a high density of $\alpha 2$-adrenoceptors as well as 5-HT neuronal cell bodies (24). Our previous study that clonidine-induced decreases of the 5-HTP accumulation in the dorsal raphe nucleus were abolished by 6-OHDA pretreatment (19) suggested that noradrenergic neurons are involved in the inhibitory action of clonidine on 5-HT biosynthesis in the dorsal raphe nucleus. Geyer and Lee (9) reported that clonidine suppressed the 5-HT neuronal firing in the dorsal raphe nucleus which was mediated through the noradrenergic neurons. These results are in agreement with the present data showing that clonidine-induced decreases in CSF 5-HT levels were prevented by noradrenergic destruction. Therefore, the CSF 5-HT levels may partially reflect the serotonergic neuronal activity in the dorsal raphe nucleus.

More recent studies have pointed out that extracellular 5-HIAA levels do not reflect the serotonergic neuronal activity. These studies showed that the extracellular 5-HIAA levels during potassium $\left(\mathrm{K}^{+}\right)$-stimulation (25) or experimental ischemia (26) did not change in parallel with the 5-HT release. In our experiment using in vivo microdialysis, extracellular 5-HIAA levels were not affected by $\mathrm{K}^{+}$-stimulation despite increases in 5-HT levels (22). De Simoni et al. (27) have shown that the caudate 5-HIAA levels did not increase following administration of tryptophan (Trp), even though brain 5-HIAA contents increased. In contrast, some investigators reported that the extracellular 5-HIAA levels in the striatum (28) and the CSF 5-HIAA levels rose after Trp administration (29). We also observed that systemic administration of 5-HTP (50 and $150 \mathrm{mg} / \mathrm{kg}$, i.p.) caused increases in CSF 5-HIAA levels in parallel with increases in CSF 5-HT levels (30). Moreover, 5-HT neurotoxin, 5,7-dihydrox ytryptamine, decreased not only CSF 5-HT but also CSF 5-HIAA concentrations (16). Thus, the CSF 5-HIAA concentrations changed simultaneously with the CSF 5-HT levels. These results strengthen the premise that the 5-HIAA levels in the CSF provide a reliable index of central serotonergic nerve activity.

In summary, the present study suggests that clonidine acts to inhibit the serotonergic neuronal activity, which is partially mediated via the $\alpha 2$-adrenoceptors. It indicates, moreover, the possibility that noradrenergic nervous systems are involved in the clonidine-induced inhibition of serotonergic neuronal activity. In other words, the physiological and functional interactions between serolonergic and noradrenergic nervous systems exist in vivo, i.e., the activity of serotonergic neurons might be modulated by noradrenergic neurons. The present study also 
demonstrates that the determination of CSF 5-HT and 5-HIAA concentrations in anesthetized rats is a useful and significant method for studying the pharmacological effects on the central serotonergic neuronal activity including biosynthesis, metabolism and/or release.

\section{References}

1. J.M. BARABAN and G.K. AGHAJANIAN, Brain Res. 204 1-11 (1981).

2. V.M. PICKEL, T.H. JOH and D. REIS, Brain Res. 131 197-214 (1977).

3. S.L. FOOTE, E.B. FLOYD and G. ASTON-JONES, Physiol. Rev. 63 844-914 (1983).

4. J.M. CEDARBAUM and G.K. ACHAJANIAN, Eur. J. Pharmacol. 44 375-385 (1977).

5. S.Z. LANGER, Pharmacol. Rev. 32 337-362 (1981).

6. K. STARKE, Rev. Physiol. Biochem. Pharmacol. 77 1-124 (1977).

7. T.C. Westfall, Physiol. Rev. 27 659-728 (1977).

8. J.F. REINHARD JR and R.H. ROBERT, J. Pharmacol. Exp. Ther. 221 541-546 (1982).

9. M.A. GEYER and E.H.Y. LEE, Biochem. Pharmacol. 33 3399-3404 (1984).

10. J. MAJ, L. BARAN, M. GRABOWSKA and H. SOWINSKA, Biochem Pharmacol. 22 2679-2683 (1973).

11. H-W. CLEMENT, D. GEMSA and W. WESEMANN, Eur. J. Pharamacol. 217 43-48 (1992).

12. L.X. GUBEDDU, I.S. HOFFMANN, J. DAVILA, Y.R. BARBELLA and P. ORDAZ, Life Sci. 35 13651371 (1984).

13. I.N. MEFFORD and N.A. GARRICK, Brain Res. 492 377-380 (1989).

14. G.M. ANDERSON, I.N. MEFFORD, T.J. TOLLIVER, M.A. RIDDLE, D.M. OCAME, J.F. LECKMAN and D.J. COHEN. Life. Sci. $\underline{46}$ 247-255 (1990).

15. M. MATSUMOTO, H. TOGASHI, M. YOSHIOKA, M. HIROKAMI, K. MORII and H. SAITO, J. Chromatogr. 526 1-10 (1990).

16. M. MATSUMOTO, H. TOGASHI, M. YOSHIOKA, K. MORII, M. HIROKAMI, M. TOCHIHARA, T. IKEDA, Y. SAITO and H. SAITO, Life Sci. 48 823-829 (1991).

17. L. QUINTIN, G. HILAIRE and J.F. PUJOL, Neuroscience 18 889-899 (1986).

18. E. TIBIRICA, C. MERMET, J. FELDMAN, F. GONON and P. BOUSQUET, J. Pharmacol. Exp. Ther. 250 642-647 (1989).

19. M. YOSHIOKA, M. MATSUMOTO, H. TOGASHI, C.B. SMITH and H. SAITO. Neuroscience Lett. $\underline{139}$ 53-56 (1992).

20. A.L. FRANKHUYZEN and A.H. MULDER, Eur. J. Pharmacol. 63 179-182 (1980).

21. G. MAURA, A. GEMIGNANI and M. RAITERI, Naunyn-Schmiedeberg's Arch Pharmacol. 334 323-326 (1982).

22. M. YOSHIOKA, M. MATSUMOTO, H. TOGASHI, C.B. SMITH and H. SAITO, Neuroscience Lett. 139 $57-60(1992)$.

23. M. LINDVALL, L. EDVINSSON and C. OWMAN, Science 201 176-178 (1978).

24. J.R. UNNERSTALL, T.A. KOPAJTIC and M.J. KUHAR, Brain Res. 7 69-101 (1984).

25. P. KALEN, R.E. STRECKER, E. ROSENGREN and A. BJORKLUND, J. Neurochem. 51 1422-1435 (1988).

26. G.S. SARNA, T.P. OBRENOVITCH, T. MATSUMOTO, L. SYMON and G. CURZON, J. Cereb. Blood Flow Metab. $\underline{9}$ S184 (1989).

27. M.G. DE SIMONI, A. SOKOLA, F. FODRITTO, G. DAL TOSO and S. ALGERI, Brain Res. 411 89-94 (1987).

28. G.S. SARNA, P.H. HUTSON, M.T. O'CONNELL and G. CURZON, J. Neurochem. 56 1564-1568 (1991).

29. P.H. HUTSON, G.S. SARNA, B.D. KANTAMANENE and G. CURZON, J. Neurochem. 44 1266-1273 (1985).

30. H. TOGASHI, M. MATSUMOTO, M. YOSHIOKA, M. MINAMI and H. SAITO. Biogenic amines $215-27$ (1992). 